\title{
In search of turbulence \\ Labour market mobility and job stability in Germany
}

\author{
by Marcel Erlinghagen and Matthias Knuth \\ Institut Arbeit und Technik \\ Abteilung Arbeitsmarkt \\ Munscheidstraße 14 \\ D-45886 Gelsenkirchen \\ Germany \\ erlinghagen@iatge.de \\ knuth@iatge.de
}

Paper prepared for the $3^{\text {rd }}$ International Congress of the Work \& Labour Network

of the International Sociological Association (ISA)

"Labour, Globalisation and the New Economy"

May 22-25 2002, Osnabrück (Germany) 


\begin{abstract}
In the transition from an industrial society to a service society, particularly changes on the labour market are likely to occur. A number of authors assert that these changes will result in an increasing external-numerical flexibility, which is assumed to affect labour market processes in terms of a generally higher labour market mobility and a decreasing employment stability ('high-velocity-labourmarket').

This paper examines the hypothesis of a growing importance of numeric-external flexibility, applying simple descriptive statistical methods to the event-history data of the IAB Employment Subsample for the West German labour market in the years 1976 to 1995 . There is no evidence for an accelerating labour market dynamic, but rather for a stagnating or even slightly declining labour market mobility since the 1970s. Furthermore, the job stability does not decrease over time, as one might have expected, but increases.

Although the general results show no increasing fluctuation and instability, it is conceivable that service-sector jobs have become more unstable but that this increased instability is cancelled out by a considerable stabilisation of employment relationships in manufacturing. However, in the end of the paper it turns out that there is no evidence for such contrasting developments in the 'old' and 'new' labour markets.
\end{abstract}




\section{Introduction}

Since the heyday of industrialism, the German employment system, and that of many other countries as well, has undergone some fundamental changes. Thus the importance of skills and of "lifelong" learning has certainly increased, as have women's labour market participation and the diversity of new and more flexible working-time forms (cf. Mayer/Müller 1994: 265). There has been no shortage of attempts to characterise this change by locating it within major trends whose effects are said to be all-embracing and which, denoted by such terms as "globalisation" and “individualisation" (cf. for example Rogowski/Schmid 1997) or "tertiarisation" (cf. for example Häußermann/Siebel 1995), are the object of much debate. These trends not only affect society as a whole but are also the cause of changes in social subsystems such as the labour market. There has also been much discussion in Germany of various mutually complementary and, in part, overlapping developments, some of which fits into the international debate on the "end of work" (Rifkin 1996; Giarini/Liedtke 1998; for a critical perspective see G. Wagner 2000; Knuth 2000), while other aspects reflect specific problems in the German labour market, such as the debates on the "erosion of the standard employment relationship" (Mückenberger 1989; Zukunftskommission 1996; Hoffmann/Walwei 1998; for a critical perspective see A. Wagner 2000) or on the growing importance of the "entrepreneurial worker" (Voß 1998; for a critical perspective see Bosch 2000).

A particular focus of the debate on the "future of work" is the evolution of labour mobility. Labour turnover and the duration of employment relationships are key issues in both the German and the international debates on the functioning and future of the labour market. It has emerged from these debates that the general findings on labour market mobility and the duration of employment relationships reported in the literature are not wholly unambiguous. Some authors claim to have observed increased labour market mobility and job insecurity in Great Britain (Booth et al. 1999) or the USA (Swinnerton/Wial 1995; Valetta 1999), while others refute these findings and suggest that, despite the alleged (and ongoing) increase in flexibility and deregulation, there is little evidence of any (unambiguous) effects on mobility and duration of employment relationships (cf., 
for example, on Great Britain, Burgess/Hedley 1998 and on the USA, Diebold et al. 1996; Neumark et al. 1999; Gottschalk/Moffitt 1999).

As far as external flexibility in the German labour market is concerned, many commentators start from the assumption of a long-established but now strengthening general trend towards a "high-velocity labour market" that is increasingly shaping the "future of work". In such a turbulent labour market, individual employment histories will, over time, "become increasingly unpredictable and chaotic compared with those of the past" (Rogowski/Schmid 1997: 577; own translation). Labour markets in the "risk society" are said to be characterised by a constantly advancing, all-embracing process of "destructuring": "In this way a new division of the labor market is created between a uniform standard industrial society labor market and a flexible, plural risk society market for underemployment, where the second market is quantitatively expanding and increasingly dominating the first" (Beck 1992: 144-145; cf. also for example Offe 1994; Mutz et al. 1995). This view is by no means confined to Germany. Thus the paper by Doogan (2001) shows that a very similar debate to the German one on the alleged decline in job stability is being conducted in Great Britain. The same can be said of a number of other industrialised countries (for a short selection of sources see OECD 1997: 137; Auer/Cazes 2000). The consequence of this increased external labour market flexibility is said to be a levelling out of employment opportunities and risks; uncertainties that in industrial societies were unevenly distributed along clearly defined socio-economic demarcation lines are said to be becoming increasingly generalised. The old division between "core" and "peripheral" workforces is said to be dissolving into general employment instability.

Any attempt to ascertain whether increasing external flexibility in the German labour market of recent decades, during the transition from the industrial to the service economy, has actually led to the emergence of an increasingly "highvelocity labour market" with a growing risk of unemployment must begin with an empirical analysis of (a) labour market mobility, (b) job stability and (c) the extent of the experience of unemployment. This analysis is conducted in Section 1, as part of a descriptive analysis of the West German labour market as a whole. The labour market for service workers is examined in greater detail in Section 2, since it is in this segment that a high-velocity labour market is most likely to emerge. 
The main question addressed in this section is how the stability of employment relationships in the service sector has changed in the course of the investigation period. In Section 3, finally, we give an overall assessment of the results of our investigation.

\section{The evolution of the German labour market between 1976 and 1995: General Results}

\subsection{Hypotheses and data set}

The following three hypotheses provide the starting point for our analysis:

Hypothesis 1: Employee mobility in the external labour market has generally increased since the 1970s.

Hypothesis 2: The stability of employment relationships has declined since the 1970s.

Hypothesis 3: $\quad$ Experience of unemployment has become increasingly become increasingly normalised since the 1970s.

If turbulence really is becoming an established feature of the German labour market, then these hypotheses should be confirmed in the course of the following empirical analysis.

In order to be able to test these hypotheses, we require data capable of depicting dynamic processes. So-called "event history data" are best suited to this task. Such data capture changes in the phenomena under investigation on a continuous basis. In this case, "continuous" means that changes of status and hence durations are captured sufficiently precisely with regard to the problems to be investigated and the range of statuses thereby defined.

The so-called IAB employment subsample (IABES) is particularly well suited for use as a data set for the analysis of employment careers in Germany. The IABES contains exact daily data on the employment careers of some 560,000 individuals over the period between 1975 and 1995. The data set is based on a 1\% sample of the insurance accounts that the Federal Labour Office (Bundesanstalt für Arbeit, or BA) maintained in respect of employees liable to pay social security 
contributions between 1975 and 1995. These "process-produced data"2 are supplemented by data on periods of unemployment ${ }^{3}$ during which a claimant received benefits and on certain characteristics of the establishments that employed individuals in the subsample during the period of observation. This corresponds to about 7.8 million employment or benefit payment notifications, with each individual record containing 35 variables (cf. Bender et al. 1996; Bender/Haas/Klose 2000).

Our analysis will include only those individuals who were employed throughout their working lives solely in West German establishments; the concentration on West German employees ensures that the period of analysis is sufficiently long. ${ }^{4}$ Furthermore, second jobs (multiple employment relationships) are not taken into account and individuals in apprenticeship training are also excluded from the analysis. The analysis presented here does not distinguish between part-time and full-time employment, although the data set does contain this information (for results regarding to part-time and full-time employment see Erlinghagen/Knuth 2002).

It should be noted that the IAB employment subsample enables us to consider only a limited time horizon. Thus there are episodes that had already begun when the observation period started on 1 January 1975 and episodes that had not

1 Employers in Germany are legally obliged to register their employees with the various social security agencies (pension, health and unemployment insurance). These agencies include the Federal Labour Office in Nuremberg, which is responsible for unemployment insurance. Relevant data on each employee taken from the employer declarations is held there electronically in individual "insurance accounts".

2 Process-produced data are "data that are required and gathered for administrative purposes or to assist public institutions (particularly social security agencies) to discharge their duties" (Schmähl 1985: 277; own translation). The particular advantage of process-produced data over survey data is that they provide exact data on a large number of individuals over a long period of time (Schmähl/Fachinger 1994). The disadvantage of such data is that they are primarily gathered in order to provide adequate information for administrative procedures and may, therefore, lack certain information desirable from a research perspective.

3 The IABES documents only those spells of unemployment during which individuals in the sample receive unemployment benefits from the Federal Labour Office; periods of unemployment without entitlement to benefits are not recorded. The "benefit recipient rate", that is the share of those entering unemployment who receive benefits, declined from an average of 76.8 per cent in the 1980 s to an average of 69.4 per cent in the 1990 s (cf. IAB 2000: 62f.). Moreover, the IABES does not record all types of benefit. The relevant IABES variable has three categories: "unemployment benefit", "unemployment assistance" (paid to workers who have exhausted their entitlement to unemployment benefit) and "training allowance" (cf. Bender/Haas/Klose 2000: 5).

4 On the development of the East German labour market after 1990, see for example Solga/Diewald (2001). 
finished when the observation period ended on 31.12.1995. In the first case, we speak of left-censored and in the second case of right-censored data (cf. Blossfeld/Rohwer 1995: 34ff). Because of this censoring problem, employment data from 1975 are not included in our analysis at all, while data from 1995 are included only in part.

The data set imposes three further restrictions on our analysis.

Firstly, any analysis of the IAB employment subsample must be confined to insurable employment. Consequently, the self-employed, civil servants and those in marginal part-time employment ${ }^{5}$ are not included in the analysis. However, since at the end of the investigation period about 80 per cent of the economically active population was still in insurable employment, making it by far the most widespread employment form in the German labour market (Hoffmann/Walwei 1998), this data set captures the overwhelming share of labour market participants.

Secondly, it should be noted that the IAB employment subsample provides data only up to 1995; consequently, more recent developments in the labour market cannot be depicted by means of this data set. However, it can be used to examine long-term trends, which include the notion of the "high-velocity labour market". Thirdly, the data set provides evidence only on objective job stability; in other words, the data can be used only to ascertain how long a particular employment relationship lasts. Employees' subjective perceptions of these relationships may be different and are not the object of the present investigation. The same applies to contractual aspects: fixed-term contracts with the same employer and succeeding one another without interruption will appear as one long-lasting employment relationship. As for the nature of separations, the data set makes no difference between dismissals, quits and voluntary annulments. And finally, the data set does not provide any information on the pressure to which employees are exposed in the workplace to operate more flexibly.

5 Less than 15 hours per week or less than a monthly earnings threshold, which used to be dynamic, was fixed at 630 DEM in 1999 and, starting from 2002, was rounded up to 325 Euros. 


\subsection{Labour market mobility between 1976 and 1995}

The evolution of labour market mobility can be reproduced with the aid of suitable flow values. The IAB employment subsample can be used to calculate entry and exit rates by dividing the number of employment relationships begun or ended in a calendar year by the total number of employment relationships. ${ }^{6}$ The average of the entry and exit rates, the so-called labour turnover rate (LTR), is calculated as described by Cramer/Koller (1988) by dividing the total number of employment relationships begun and ended in that year by the total (double) number of employees in a year. ${ }^{7}$ Thus the LTR is an indicator of total labour market mobility.

Figure 1 shows the evolution of entry, exit and labour turnover rates in the West German labour market, together with the indexed evolution of employment between 1976 and $1995 .^{8}$ The number of persons in insurable employment in West Germany rose by 10 per cent between 1976 and 1995. During the employment boom of the early 1990s, the increase actually reached a peak of 15 per cent. Both entries into and exits out of employment show a procyclical pattern. Thus overall mobility is greater during upturns than during downturns. This effect can be explained by the fact that the replacement chains become longer in upturns and act as a multiplier on mobility (cf. Schettkat 1996).

In order to test hypothesis 1 , which posits a general increase in mobility, we must try to eliminate these cyclical influences. This is only partially possible, of course, since only one full cycle is completely covered by the data set and one that was, moreover, atypically influenced by German unification. In 1976, between the oil price shocks and the temporary peak of 1980, the West German LTR was 30 per

6 An "entry" is defined as the start of a new, insurable employment relationship. An "exit" is defined as the ending of an existing insurable employment relationship, although periods during which the employment relationship is merely suspended (because of extended periods of illness or maternity/paternity leave, for example) are considered to be part of an ongoing employment relationship. Transitions from full-time to part-time employment and vice versa within the same establishment are regarded as a continuation of the existing employment relationship.

7 In order to simplify the calculations, we differ from Cramer/Koller (1988) in taking as the reference value not the annual average number of employees but rather the number of people in employment as at 30 September each year. This leads to slightly different rates, but does not alter the trends.

8 The exit rate for 1995, and hence the labour turnover rate as well, is systematically underestimated because of right-censoring, since only exits up to 1 December 1995 are included in the calculation. 
cent; in 1995, two years before the employment low point was reached, it had fallen to 25 per cent. It is known from official statistics that labour turnover rates did not reach the 1976 level again, not even in 1997 and 1998 ${ }^{9}$, which are perhaps more comparable with 1976 by virtue of their position in the cycle. Even during the employment boom of the 1990s, when the LTR was around 30 per cent, mobility in the West German labour market was lower (albeit only slightly) than in the weaker employment boom of the late 1970s. It is also notable that, despite the dramatic collapse in employment in the mid-1990s, the labour market at this point was not any less "mobile" than during the employment downturn of the first half of the 1980s, which was less extensive in both absolute and relative terms (LTR 1983: 24 per cent; LTR 1995: 24 per cent).

Figure 1: Entry, exit and labour turnover (LTR) rates and evolution of employment (index: 1976=100), West Germany, 1976-1995

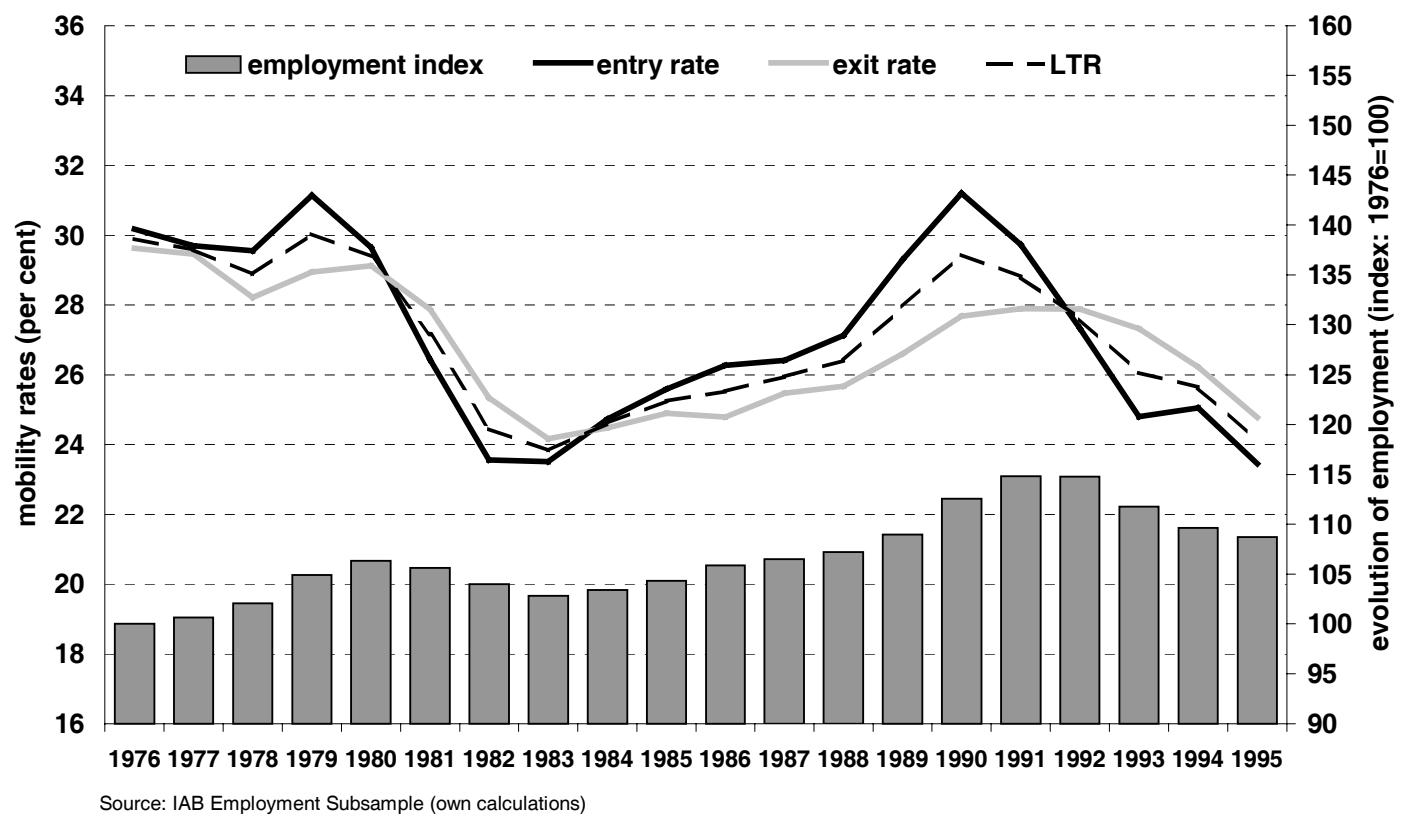

Thus the labour turnover rates do not provide any evidence of a general increase in the labour market mobility of workers in insurable employment during the observation period. ${ }^{10}$ In fact, labour mobility in West Germany is astonishingly little influenced by supposed or actual economic and social changes. Indeed, the

9 More up-to-date figures are not currently available because of a change in employment statistics.

10 Calculations not presented here for space reasons also show that the relative frequency of immediately inter firm transitions (i.e. those without an intermediate period of unemployment or non-activity) did not increase during the observation period if cyclical fluctuations are taken into account (cf. Erlinghagen/Knuth 2001). 
trend in labour mobility even seems to point downwards. Thus the first hypothesis must be unequivocally rejected.

\subsection{Stability of employment relationships}

The data derived from the IAB employment subsample are daily event history data that make it possible to ascertain the exact duration of employment relationships. With the aid of so-called survivor rates, the stability of employment relationships can be calculated and also represented graphically through timedependent survivor probabilities (on the calculation of survivor rates cf. Blossfeld/Rohwer 1995). In this way, we can superimpose employment relationships that begin at different points of calendar time on an observation period axis and pool them at will, which allows us to compare, for example, the stability of employment relationships that began between 1976 and 1980 with the stability of those that began between 1986 and $1990 .{ }^{11}$

Figure 2 shows the survivor rates for employment relationships that began in these two periods. If the employment relationship began between 1976 and 1980, it is included here in the 1976-1980 entry cohort (EC 1976-1980); if it began at any time between 1986 and 1990, it is included in the 1986-1990 entry cohort (EC 1986-1990). ${ }^{12}$ The survivor rate measures the probability of an employment relationship that began in a particular entry cohort not ending within the observation period plotted on the time axis. The maximum period of time observed here is five years $(1,825$ days). Looking at these diagrams the other way round, we can ask how long it takes in each instance until only a certain percentage (e.g. 50 or 25 per cent) of the employment relationships that began in the observation period remain.

The falling survivor rate in Figure 2 represents the fact that the longer the time that has elapsed since the entry date, the less likely it is that an employment relationship still exists. The relative path of the curve is of decisive importance in

11 The reference here is to employment relationships not to individuals. In other words, in calculating the survivor rate, we take into account all changes of employer during the observation period, and hence all new employment relationships entered into, rather than the number of individuals making such transitions. In the case of "job hoppers", therefore, each new employment relationship entered into will be taken into account. This is more precise than cross-sectional surveys of tenure, such as the European Labour Force Survey, which can capture only a single change of employment relationship within a 12-month period.

12 These two entry cohorts were selected because the two periods in question, 1976-80 and 198690, were periods of employment growth. 
testing the hypothesis of declining job stability. A group of employment relationships - in this case five-year entry cohorts - is shown to be all the more stable the higher the path of the corresponding survivor rate in the coordinate system is. In Figure 2, the path of the curve for the later entry cohort is higher than the curve for the earlier cohort. This means - contrary to hypothesis 2 - that employment relationships that began at the end of the 1980s were more stable than those that began at the end of the 1970s. ${ }^{13}$

Figure 2: Survivor rate for new employment relationships (total), West Germany, 1976-1980 and 1986-1990 entry cohorts (ECs)

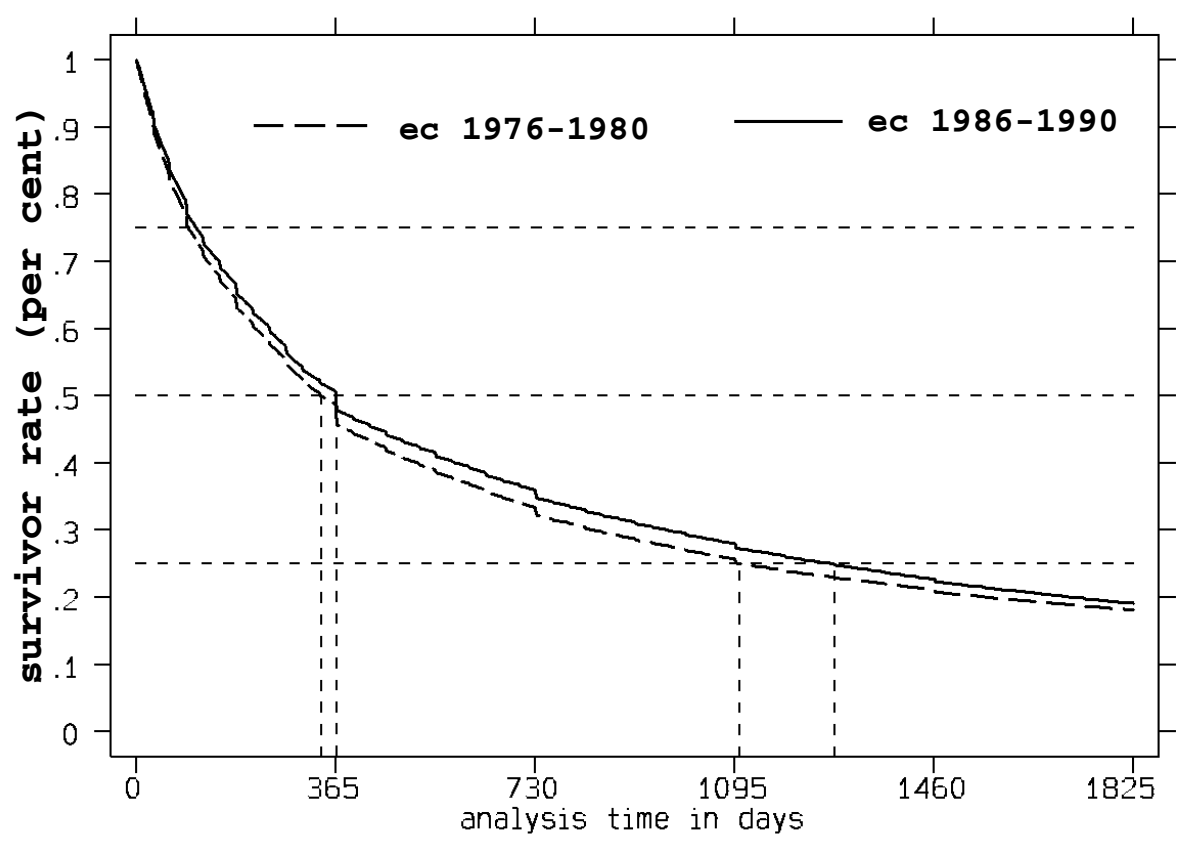

Source: IAB Employment Subsample (own calculations)

And yet how pronounced has the increase in job stability been? One indication of this is the period of time that elapses until a certain survival probability is reached. For example, 50 per cent of the employment relationships that began between 1976 and 1980 had already ended within approximately 340 days, while the median duration of employment in the new job for the 1986-1990 EC is 365 days.

13 On these premises and with the dataset used here, entry years after 1990 cannot be analysed in this way because of right-censoring problems. If we were to content ourselves with shorter observation periods, more recent entry years could be included in the analysis. Furthermore, entry cohorts could be defined more narrowly, comprising only one calendar year. Such differentiated analyses, not shown here for space reasons, reveal that the stabilisation of employment relationships occurred mainly during the second half of the eighties but that this trend was not reversed until 1993, the latest possible year of observation (cf. Erlinghagen/Knuth 2002). 
In other words, the median job duration increased over a ten-year period by 25 days.

This increase in job stability becomes even more evident if the last quartile is considered. In the case of the employment relationships entered into between 1976 and 1980, it took three years (1,095 days) for only one quarter of them to be still in existence, whereas in the case of the younger entry cohort a survivor rate of 25 per cent was not reached until around six months later.

Thus survivor analysis reveals that one in two new jobs is relinquished within approximately one year, making Farber's conclusion that "most jobs end early" (Farber 1999: 2453) applicable to the German labour market as well. However, comparison of the two entry cohorts does not reveal any destabilisation over time. On the contrary: over the course of the observation period the stability of new employment relationships increases rather than declines. ${ }^{14}$ Consequently, the second hypothesis must also be rejected.

\subsection{Experience of unemployment: increasingly the norm?}

In order finally to ascertain whether experiences of unemployment are becoming more frequent, we compared the number of persons experiencing at least one day's unemployment in a calendar year with the number of persons active in the labour market (unemployed and those in insurable employment). The "unemployment experience rate" thus obtained indicates the share of labour market participants who experienced unemployment in any one year during the observation period. ${ }^{15}$

14 Another possible way of examining the stability of employment relationships is to calculate average actual job tenures (cf. Hall 1982; Ureta 1992). It transpires that in the period in question here average actual job tenures in Germany in fact increased (ILO 1996; OECD 1997).

15 The procedure used to calculate unemployment experience rates is different from that adopted by Franz (1999: 353f; cf. also Steiner/Kaltenborn 1995: 38), who divides the number of entries into unemployment by the number of economically active individuals, thereby taking account of multiple spells of unemployment. Our simplified method avoids the problem, which can be resolved only with difficulty, of distinguishing breaks in unemployment for administrative or benefit regulation reasons, such as failure to register or benefit cut-off periods, from re-entries into employment followed by a further spell of unemployment. If this distinction is ignored when multiple spells of unemployment are taken into account, then it is easy to confuse increasing restrictions on the payment of social security benefits with increased risk in the labour market. 
Figure 3 shows the shares of labour market participants in each year who (a) experienced only employment (not a single day's unemployment registered; at least one day's insurable employment), (b) experienced only unemployment ${ }^{16}$ (not a single day's insurable employment, at least one day's unemployment registered) and (c) were in insurable employment in the year in question and also experienced unemployment (at least one day in each case). ${ }^{17}$

Figure 3: Unemployment experience rate and employment rate (total), West Germany 1980-1995

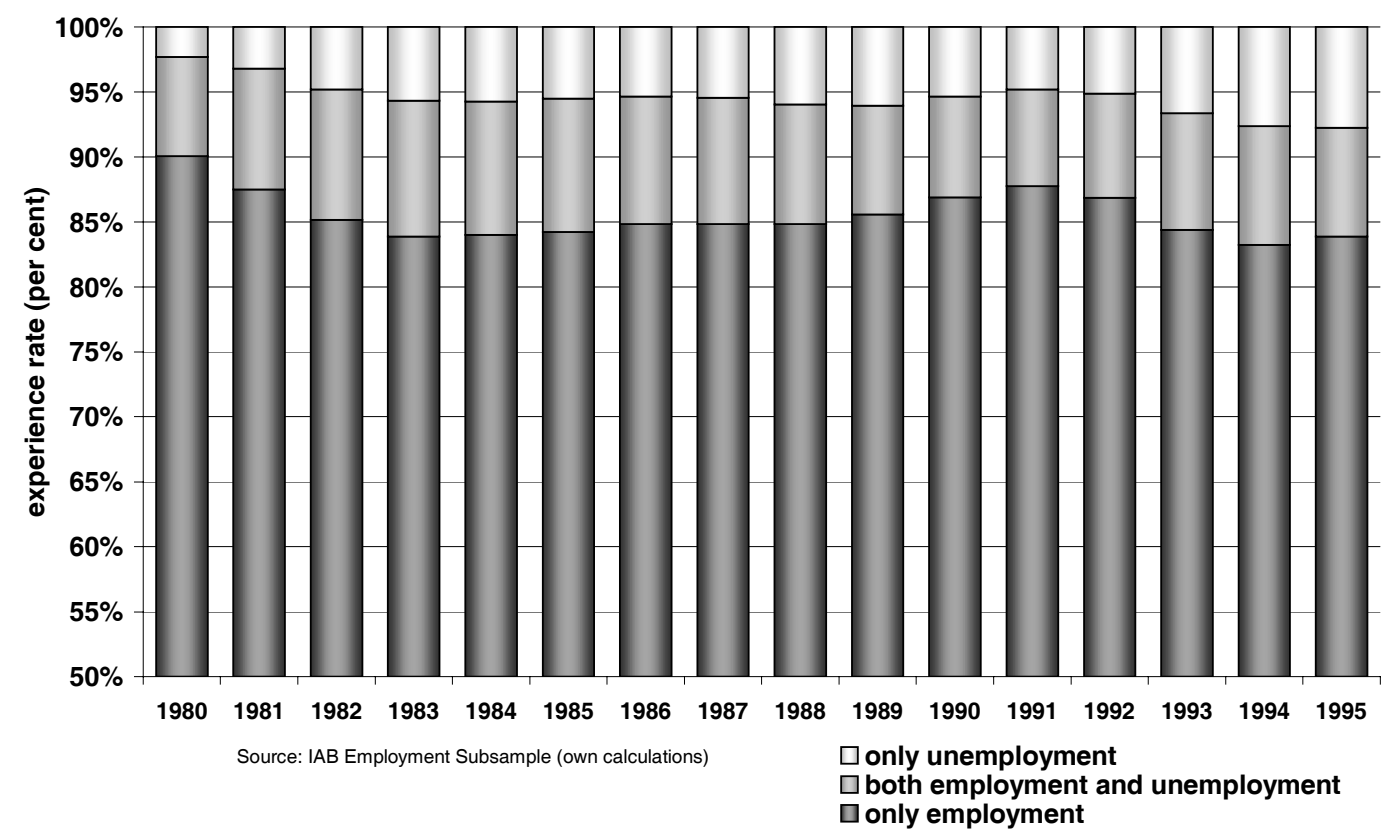

In 1980, more than 90 per cent of labour market participants experienced only employment, while the unemployment experience rate for the same year was just under 10 per cent (the two upper sections of the bars in Figure 3 taken together). Although this value rises to a peak of around 16 per cent in 1994, any attempt to interpret these figures must take account of fluctuations in the economic situation. It turns out that the unemployment experience rate was not significantly higher during the employment downturn of the first half of the 1990s than in the less pronounced downturn of the early 1980s. Thus the experience of unemployment

16 It should be remembered that the data set used here captures unemployment only through the payment of benefits - cf. footnote 5 .

17 The years 1975 to 1979 are not included in the analysis of unemployment (although data for this period are also in principle available in the IABES) because distortions might occur due to the under-recording of unemployment spells in the data set (cf. Bender et al. 1996: 27). 
has not become much more frequent and as a result the third hypothesis must also be rejected..$^{18}$

Figure 3 reveals something else as well. There is obviously an expanding category of unemployed individuals who do not make the transition out of unemployment back into employment or who, for whatever reasons, do not attempt to do so. In 1980, only 2.5 per cent of labour market participants experienced only unemployment; by 1995, the percentage had increased to around 7.5 per cent. This increase went hand in hand with an increasingly unequal distribution of the total volume of unemployment (Karr 1997; Kurtz 2000). Examination of which groups are particularly badly affected by this "hardened" form of unemployment falls outside the scope of this paper. We will merely note that the same data set was used in an attempt to ascertain the share of workers effecting the transition from employment to retirement by taking unemployment benefits as a pathway. It was concluded that in 1993, on a very conservative estimate, more than one tenth of the total volume of unemployment was attributable to unemployment of the "early retirement" type (cf. Kalina/Knuth 2002). However, if we were to adduce the use (or abuse) of unemployment benefit as an instrument of early retirement ${ }^{19}$ as evidence to support the notion that "unemployment is part of a normal employment career", then we would be ignoring some of the fundamental aspects, social definitions and subjective meanings of old age unemployment as the final phase of employment careers.

\section{Labour market dynamics in the service society}

The findings presented up to this point show that a high-velocity labour market has by no means become established in Germany (see also for example the results by Kurz/Hillmert/Grunow 2002). Nevertheless, it may be that there are individual segments of the labour market in which employment relationships have become more unstable over time, against a general trend that may possibly, therefore, be concealing contrary developments and an increasing polarisation of job stability. Thus it is conceivable, for example, that service-sector jobs have become more

18 Cf. also the longitudinal analysis carried out for the period 1955-1995 using the "supplementary sample I" (Kurtz 2000).

19 On the mechanisms at work here cf. Knuth 1999. 
unstable but that this increased instability is cancelled out by a considerable stabilisation of employment relationships in manufacturing. Such contrasting developments in the "old" and "new" labour markets would force us into a differentiated assessment of the general findings presented in Section 1.

\subsection{What does "service society" mean?}

If the increasing trend towards tertiarisation that is implicit in the notion of the "service society" is to be verified, then we need to find criteria for distinguishing service activities from manufacturing activities. The three concepts "industry", "occupation" and "sphere of activity" play a decisive role in this regard.

In the past, the tertiarisation phenomenon was investigated primarily from an industry perspective. From this point of view, the German service sector seemed to be underdeveloped in comparison with the USA, for example, and the problems of the German labour market were attributed to this alleged "service gap" (Klös 1997). In the course of the debate on this "service gap", however, the basis for determining the extent of tertiarisation in the German labour market shifted from individual industries to occupations and/or activities. The main reason for this change in the basis of measurement is that, in Germany in particular, service activities have not been completely outsourced by manufacturing firms and that the industry-based approach therefore underestimates the extent of tertiarisation (cf., for example, Haisken-DeNew et al. 1996; 1998; Wagner 1999; Bosch 2001a; Freeman/Schettkat 1999).

In theory, therefore, an activity-based approach is better able to capture the true extent of tertiarisation. ${ }^{20}$ The IAB employment subsample contains data on activity based on the Federal Labour Office's three-figure occupational code; these codes relate to the job or activity actually being carried on and not to the occupation or trade for which members of the sample population might have been trained. ${ }^{21}$ In order to be able to group activities into (a) agriculture and mining (b) manufacturing and (c) services, the 275 occupations/groups of occupations have

20 An industry-based analysis of job stability will be found in Knuth/Schräpler/Schumann (2001).

21 Initially, 334 occupations can be identified at 3-figure level; for reasons of anonymity, 231 occupations retain their original classification, while the remaining 103 occupations are brought together under a single 3-digit figure, so that finally 275 occupations or groups of occupations can be identified (Haas/Bender/Klose 1999: 4). 
to be allocated one of the three categories; group (a), being very small, is ignored in the following analyses. The allocation is based essentially on the frequency distribution of the characteristics and/or principal tasks involved in the various activities, as listed by Parmentier/Schade/Schreyer (1993) for all occupations and groups of occupations. ${ }^{22}$

\subsection{The quantitative importance of service activities in the German employment system}

The data from the IAB employment subsample confirm the findings of studies of the share of service-sector employees in Germany based on other data sources (cf., for example, Haisken-DeNew et al. 1996; 1998). Figure 4 shows, firstly, that the number of employees in service occupations has risen continuously, particularly since the beginning of the 1980s, with the result that by 1995 there were virtually 30 per cent more employees engaged than there had been in 1975 . And whereas the number of employees in manufacturing was still rising slightly at the beginning of the investigation period, there were job losses during the employment crisis of the first half of the 1980s. This trend was only to be curbed but no longer to be reversed, even during the upturn of the late 1980s. The number of workers in manufacturing fell particularly dramatically in the first half of the 1990s: by 1995, there were about 15 per cent fewer employees in manufacturing occupations in West German firms than there had been in 1975. At the same time, the importance of service activities was increasing, both relatively and absolutely (Figure 4). In 1975, “only" about 63 per cent of employees were working in service occupations; by 1995, this share had risen to around 71 per cent. The share of manufacturing workers had fallen accordingly from 34 per cent in 1975 to 26 per cent by the end of the investigation period. ${ }^{23}$

22 There is always a certain 'arbitrary' element in such an unambiguous division into manufacturing and service activities. This is unavoidable, firstly because Parmentier/Schade/Schreyer (1993) do not by any means list exhaustive data on the distribution of characteristics; for some individual groups of occupations, moreover, no data are available because the number of cases is too small. Secondly, the distribution shifts over time, which actually hinders consistent allocation and/or necessitates adjustments from time to time.

23 The two percentages do not sum to 100 because of the exclusion of those employed in agricultural and mining occupations. 
Figure 4: Evolution of employment (Index 1975=100) and of employment structure by type of activity, West Germany 1975-1995
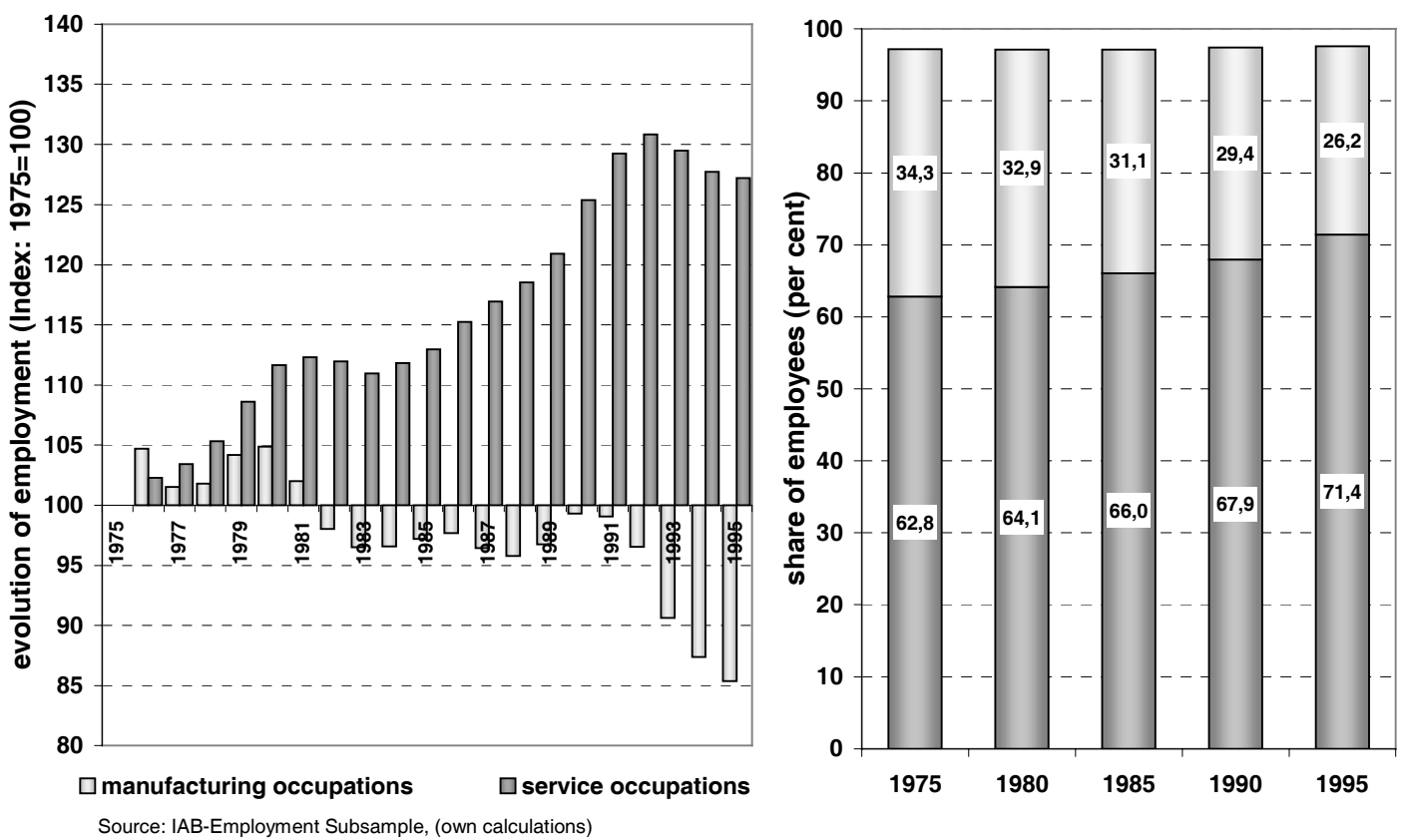

In what follows, we are concerned primarily with the stability of new employment relationships. To this end, service activities are divided into five subgroups. In addition to "production services", on the one hand, and "household and personal services", on the other, which are unambiguously characterised as involving "mainly customers", three groups of service activities are identified, each of which provides social intermediation services of various kinds: "infrastructure and transport services", "economic transaction services" and "administrative, organisational and communication services" (Table 1). 
Table 1: Five groups of service activities

\begin{tabular}{|c|c|c|}
\hline Activity group & Nature of activity & Spheres of activity \\
\hline Production services & $\begin{array}{l}\text { Control, supervision and support } \\
\text { of production processes }\end{array}$ & $\begin{array}{l}\text { - } \text { Research and development } \\
\text { - Physical protection and } \\
\text { maintenance } \\
\text { - Production control } \\
\end{array}$ \\
\hline Household and personal services & $\begin{array}{l}\text { Control, supervision and support } \\
\text { of private household production }\end{array}$ & $\begin{array}{l}\text { - Health and care services } \\
\text { - } \quad \text { Education and training } \\
\text { - } \text { Catering and tourism } \\
\text { - } \quad \text { Media, culture, leisure, sport } \\
\text { - } \quad \text { Personal finance }\end{array}$ \\
\hline $\begin{array}{l}\text { Infrastructure and transport } \\
\text { services }\end{array}$ & $\begin{array}{l}\text { Management of material flows } \\
\text { between firms and/or private } \\
\text { households }\end{array}$ & $\begin{array}{ll}\text { - } & \text { Supply and disposal } \\
\text { - } & \text { Logistics and transport } \\
\text { - } & \text { Transmission of information }\end{array}$ \\
\hline Economic transaction services & $\begin{array}{l}\text { Management of financial flows } \\
\text { between firms and/or private } \\
\text { households }\end{array}$ & $\begin{array}{ll}\text { - } & \text { Trade/commerce } \\
\text { - } & \text { Banking and insurance } \\
\text { - } & \text { Real estate business } \\
\end{array}$ \\
\hline $\begin{array}{l}\text { Administrative, organisational } \\
\text { and communication services }\end{array}$ & $\begin{array}{l}\text { Management of information } \\
\text { flows between firms and/or } \\
\text { private households }\end{array}$ & $\begin{array}{l}\text { - Administering and checking } \\
\text { - Data processing } \\
\text { - Security and justice } \\
\text { - Advertising } \\
\end{array}$ \\
\hline
\end{tabular}

\subsection{Job stability and service activities over time}

Drawing on the IABES data (see 1.3 above), Figure 5 shows the survivor rates for new employment relationships in the various service and manufacturing activities for the 1976-1980 and 1986-1990 entry cohorts. ${ }^{24}$ It is evident from the graphic that there are considerable differences in job stability between the two groups. The most stable jobs are those in economic transaction and production services, followed by those in administrative, organisational and communication services. Employment relationships in household and personal services are less stable and their survivor rates are roughly comparable with the values for manufacturing activities. The most unstable employment relationships are those in infrastructure and transport services. In this sector, 50 per cent of new employment relationships come to an end after about eight months, whereas it takes around two years for half of new jobs in manufacturing-related services, for example, to finish.

24 The allocation of an employment relationship to one of the groups of service activities takes place when the job starts; any change of activity in a continuing employment relationship are not taken into account, because the descriptive methods used here would require us to treat internal flexibility statistically as job instability, which in our view would be wholly inappropriate. 
Figure 5: Survivor rate for new employment relationships for the 1976-1980 and 1986-1990 entry cohorts (ECs), West Germany (by sphere of activity)
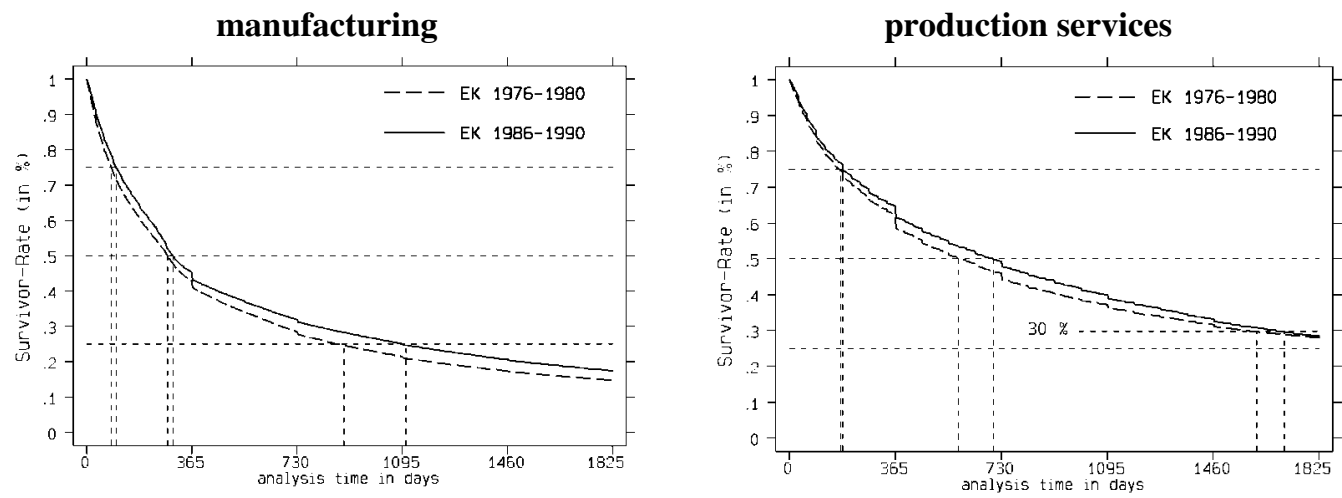

economic transaction services

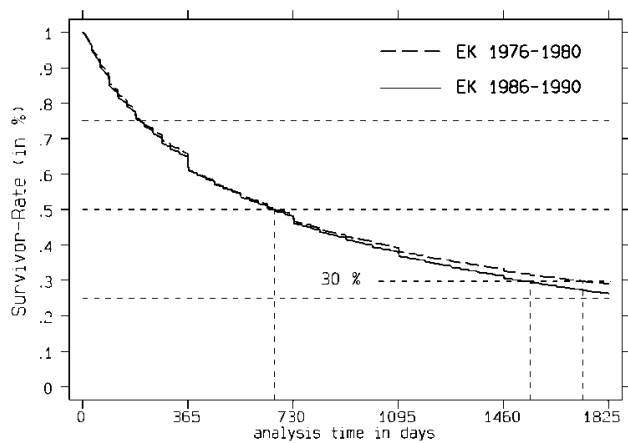

administrative, organisational and communication services

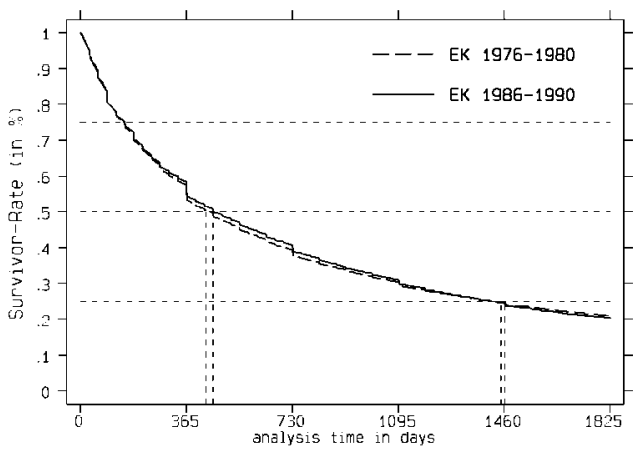

personal and household services

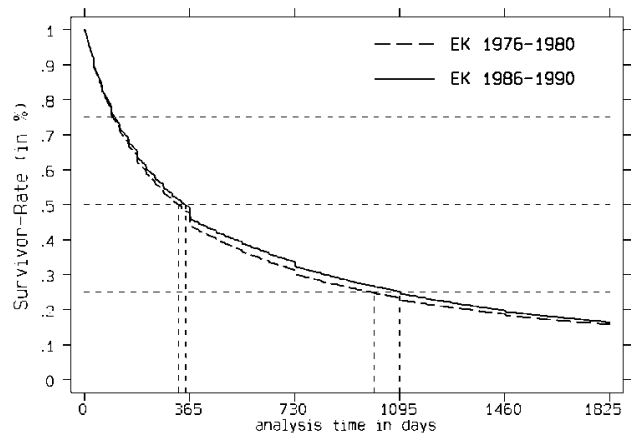

infrastructure and transportation services

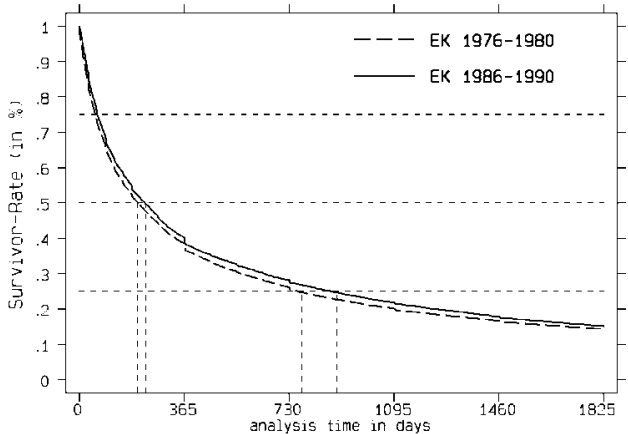

source: IAB Employment Subsample (own calculations)

Comparison of the two entry cohorts' survivor rates in the individual areas shows that new employment relationships in all the areas stabilise over time, at least within the period of five years after commencement that we are dealing with here. The only exception is economic transaction services. Although there is no difference in the median for the two entry cohorts in this segment, more employment relationships end after a "run" of about two years in the later entry cohort. Despite this destabilisation of employment relationships in economic transaction services, which runs counter to the general trend, jobs in this segment 
are still more stable, even in the later entry cohort, than those in household and personal, infrastructure and transport and administrative, organisational and communication services.

Comparison of manufacturing and service activities shows, firstly, that employment levels and job stability are evolving independently of each other. Thus the number of employees engaged in manufacturing occupations is declining significantly, although the stability of new employment relationships in this area is increasing at the same time. On the other hand, not only is the number of employees engaged in service activities growing massively but at the same time employment relationships in this growth sector are stabilising. As a result, the employment system as a whole is becoming more stable, not merely despite but actually because of its increasing tertiarisation. Service-sector employment is changing, not only quantitatively but also qualitatively.

\section{Conclusions}

The descriptive analyses conducted on the basis of the IAB employment subsample provide no evidence of any increase in general turbulence in the West German labour market between 1976 and 1995. None of the three hypotheses formulated at the outset has been confirmed: general labour market mobility is not increasing, the stability of new employment relationships is not declining and the experience of unemployment cannot be said to be becoming increasingly "normalised".

It should be borne in mind that the stabilisation of employment relationships took place during a period in which dismissal protection for permanent employment relationships remained unchanged to all intents and purposes, the use of fixedterm employment contracts was made considerably easier from 1985 onwards and the influence of trade unions and works councils was waning because of falling union density and the increasing share of employment in small firms. Despite this, firms reacted to the increased flexibility undoubtedly demanded of them as a result of the shift from the industrial to the service society not by adopting a "hire and fire" policy (external numerical flexibility) but rather by developing internal labour deployment strategies designed to produce the required flexibility in both its quantitative dimension (flexible and variable working times - cf. Bosch 2001b, 
Lehndorff 2001) and its qualitative dimension. The more advanced and broadbased training required to implement such strategies would not be worthwhile for employers or employees if employment relationships were less long-lived. In a decentralised production regime increasingly reliant on knowledge, flat hierarchies and workers' autonomy, the importance of reliable and enduring cooperation between management and workforce is undoubtedly growing. The downside of this development is the increasing complexity and intensity of work. All this would scarcely be tolerated by employees if the widespread diagnosis of destabilisation in the employment system were accurate.

The real problem that has to be dealt with in Germany is not a "high velocity labour market" but the entrenchment of unemployment. If this challenge is to be met then the actual duration of the working life must once again be extended until pensionable age. To that end, occupational transitions and further vocational training must be supported and encouraged until the end of the working life and must also be demanded by those affected. 


\section{Bibliography}

Auer, Peter / Cazes Sandrine (2000): The resilience of the long-term employment relationship: Evidence from industrialized countries; in: International Labour Review 139, 379-408.

Beck, Ulrich (1992): Risk Society. Towards a New Modernity; London: Sage. (original edition: Risikogesellschaft. Auf dem Weg in eine andere Moderne; Frankfurt a.M. 1986).

Bender, Stefan / Haas, Anette / Klose, Christoph (2000): IAB Employment Subsample 1975-1995. Opportunities for Analysis Provided by the Anonymised Subsample; Bonn: IZA Discussion Paper 117.

Bender, Stefan / Hilzendegen, Jürgen / Rohwer, Götz / Rudolph, Helmut (1996): Die IAB-Beschäftigtenstichprobe 1975-1990; Nürnberg: IAB (Beiträge zur Arbeitsmarkt- und Berufsforschung 197).

Blossfeld, Hans-Peter / Rohwer, Götz (1995): Techniques of Event History Modeling. New Approaches to Causal Analysis; Mahwah: Lawrence Erlbaum.

Booth, Alison L. / Francesconi, Marco / Garcia-Serrano, Carlos (1999): Job Tenure and Job Mobility in Britain; in: Industrial and Labor Relations Review 53, 43-70.

Bosch, Gerhard (2000): Entgrenzung der Erwerbsarbeit - Lösen sich die Grenzen zwischen Erwerbs- und Nichterwerbsarbeit auf?; in: Minssen, Heiner (ed.): Begrenzte Entgrenzung: Wandlung von Organisation und Arbeit; Berlin: Sigma, 249-268.

Bosch, Gerhard (2001a): Germany: a „service gap“?; in: Dolvik, Jon Erik (ed.): At your service? Comparative perspectives on employment and labour relations in the European private sector services; Brüssel (u.a.): P. I. E.Peter Lang, 53-101.

Bosch, Gerhard (2001b): Von der Umverteilung zur Modernisierung der Arbeitszeit: Paradigmenwechsel in der Arbeitszeitpolitik; Gelsenkirchen: Inst. Arbeit und Technik. Graue Reihe des Instituts Arbeit und Technik, Bd. 2001-02.

Burgess, Simon / Rees, Hedley (1998): A Disaggregate Analysis of the Evolution of Job Tenure in Britain, 1975-1993; in: British Journal of Industrial Relations 36, 629-655.

Cramer, Ulrich / Koller, Martin (1988): Gewinne und Verluste von Arbeitsplätzen in Betrieben - der ,Job-Turnover“-Ansatz; in: Mitteilungen aus der Arbeitsmarkt- und Berufsforschung 18, 361-377.

Diebold, Francis X. / Neumark, David / Polsky, Daniel (1996): Comment on Kenneth A. Swinnerton and Howard Wial, ,Is Job Stability Declining in the U.S. Economy?"; in: Industrial and Labor Relations Review 49, 348352.

Doogan, Kevin (2001): Insecurity and Long-term Employment; in: Work, Employment and Society 15, 419-441. 
Erlinghagen, Marcel / Knuth, Matthias (2001): Turbo-Arbeitsmarkt oder Sklerose: Auf welche Realität hat sich die Arbeitsmarktpolitik einzustellen?; in: Kittler, Klaus / ZEPRA e.V. (eds.): Paradigmenwechsel in der Arbeitsmarktpolitik. Von der Zielgruppenorientierung zur Prävention; Hamburg: VSA, 17-43.

Erlinghagen, Marcel / Knuth, Matthias (2002): Auf der Suche nach dem „TurboArbeitsmarkt". Zwischenbericht an die Deutsche Forschungsgemeinschaft (DFG) zum Projekt ,Restrukturierung des Arbeitsmarktes. Disaggregierte Längsschnittanalysen mit der IABBeschäftigtenstichprobe"; Gelsenkirchen: Institut Arbeit und Technik. Graue Reihe des Instituts Arbeit und Technik, Bd. 2002-03.

Farber, Henry S. (1999): Mobility and Stability: The Dynamics of Job Change in Labor Markets; in: Ashenfelter, O. / Card, D. (eds.): Handbook of Labor Economics; Vol. 3, S.2439-2483.

Freeman, Richard B./ Schettkat, Ronald (1999): Zwischen Fastfood und Excellence. Die Beschäftigungslücke in Deutschland im Vergleich zu den USA; in: Hamburger Jahrbuch für Wirtschafts- und Gesellschaftspolitik, 49-66.

Giarini, Orio / Liedtke, Patrick M. (1998): Wie wir arbeiten werden. Der neue Bericht an den Club of Rome; Hamburg: Hoffmann und Campe.

Gottschalk, Peter / Moffitt, Robert (1999): Changes in Job Instability and Insecurity Using Monthly Survey Data; in: Journal of Labor Economics 17, S91-S126.

Haas, Anette / Bender, Stefan / Klose, Christoph (1999): Die Anonymisierung der IABS 1975-1995 - Kurzer Abriß; paper included on the data CD Rom IABS 1975-1995.

Haisken-DeNew, John / Horn, Gustav A. / Schupp, Jürgen / Wagner, Gert (1996): Keine Dienstleistungslücke in Deutschland. Ein Vergleich mit den USA anhand von Haushaltsbefragungen; in: DIW Wochenbericht 63 (14), 221226.

Haisken-DeNew, John / Horn, Gustav A. / Schupp, Jürgen / Wagner, Gert (1998): Das Dienstleistungs-Puzzle. Ein aktualisierter deutsch-amerikanischer Vergleich; in: DIW Wochenbericht 65 (35), 625-629.

Hall, Robert E. (1982): The Importance of Lifetime Jobs in the U.S. Economy; in: American Economic Review 72, 716-724.

Häußermann, Hartmut / Siebel, Walter (1995): Dienstleistungsgesellschaften; Frankfurt a.M.: Suhrkamp.

Hoffmann, Edeltraut / Walwei, Ulrich (1998): Normalarbeitsverhältnis: ein Auslaufmodell? Überlegungen $\mathrm{zu}$ einem Erklärungsmodell für den Wandel von Beschäftigungsformen; in: Mitteilungen aus der Arbeitsmarkt- und Berufsforschung 28, 409-425.

IAB Institut für Arbeitsmarkt- und Berufsforschung (ed.) (2000): Zahlen-Fibel. Ergebnisse der Arbeitsmarkt- und Berufsforschung in Tabellen; Nürnberg: IAB (Beiträge zur Arbeitsmarkt- und Berufsforschung 101). 
Kalina, Thorsten / Knuth, Matthias (2002): Unemployment as a transition from employment to retirement in West Germany; Gelsenkirchen: Inst. Arbeit und Technik. Graue Reihe des Instituts Arbeit und Technik, Bd. 2002-05.

Karr, Werner (1997): Die Erfassung der Langzeitarbeitslosigkeit. - Ein kaum beachtetes Meßproblem; IAB-Kurzbericht 5/97 v. 7.8.1997.

Knuth, Matthias (1999): Senkung der Arbeitslosigkeit durch Ausstieg aus dem Vorruhestand. Gesellschaftliche und betriebliche Innovationserfordernisse im Umgang mit dem strukturellen und demographischen Wandel; in: Brödner, P./ Helmstädter, E./ Widmaier, B. (eds.): Wissensteilung, München und Mering: Hampp, 107-144.

Knuth, Matthias (2000): Das „Ende der Erwerbsarbeit“ oder: Die „Sauren Trauben" der Arbeitsförderer; in: Wittig-Koppe, Holger / Trube, Achim (eds.): Effekthascherei - oder: Wie effektiv ist die Arbeitsmarktpolitik; Münster: LIT, 148-177.

Knuth, Matthias / Schräpler, Jörg-Peter / Schumann, Diana (2001): Die Neuverteilung von Beschäftigungschancen und -risiken in der Dienstleistungsgesellschaft; Gelsenkirchen: Inst. Arbeit und Technik. Graue Reihe des Instituts Arbeit und Technik, Bd. 2001-01.

Kurtz, Beate (2000): 40 Jahre gearbeitet und nie arbeitslos; IAB-Materialien 4/00, $8-9$.

Kurz, Karin / Hillmert, Steffen / Grunow, Daniela (2002): Increasing Instabilities in Employment Careers? Men's Job Mobility and Unemployment in West Germany. Birth Cohorts 1940, 1955, 1964; Paper presented at the International Comparative Workshop "Globalization and Job Mobility over the Life Course of Men: The Role of Country-Specific Institutions", March 22-23 2002, Bielefeld University.

Lehndorff, Steffen (2001): Arbeitszeitkonten als Instrument einer besseren Kontrolle der Arbeitszeit durch die Beschäftigten - oder als Türöffner zur Arbeitszeitverlängerung?; in: Friedrich-Ebert-Stiftung (ed.): Moderne Zeiten: Arbeitszeitflexibilität durch Arbeitszeitkonten; Bonn: FriedrichEbert-Stiftung, 31-48.

Mayer, Karl-Ulrich / Müller, Walter (1994): Individualisierung und Standardisierung im Strukturwandel der Moderne. Lebensverläufe im Wohlfahrtsstaat; in: Beck, Ulrich / Beck-Gernsheim, Elisabeth (eds.): Riskante Freiheiten. Individualisierung in modernen Gesellschaften; Frankfurt a.M.: Suhrkamp, 265-295.

Mückenberger, Ulrich (1989): Der Wandel des Normalarbeitsverhältnisses unter Bedingungen einer „Krise der Normalität“; in: Gerwerkschaftliche Monatshefte 40, 211-223.

Mutz, Gerd / Ludwig-Mayerhofer, Wolfgang / Koenen, Elmar J. / Eder, Klaus / Bonß, Wolfgang (1995): Diskontinuierliche Erwerbsverläufe. Analysen zur postindustriellen Arbeitslosigkeit; Opladen: Leske + Budrich.

Neumark, David / Polsky, Daniel / Hansen, Daniel (1999): Has Job Stability Decline Yet? New Evidence for the 1990s; in: Journal of Labor Economics 17, S29-S64.

OECD (1997): Employment Outlook; Paris: OECD. 
Offe, Claus (1994): Vollbeschäftigung? Zur Kritik einer falsch gestellten Frage; in: Gewerkschaftliche Monatshefte 45, 769-806.

Rifkin, Jeremy (1996): Das Ende der Arbeit und ihre Zukunft; Frankfurt a.M./New York: Campus.

Rogowski, Ralf / Schmid, Günther (1997): Reflexive Deregulierung. Ein Ansatz zur Dynamisierung des Arbeitsmarktes; in: WSI-Mitteilungen 50, 568582.

Schettkat, Ronald (1996): Flows in Labor Markets. Concepts and International Comparative Results; in: Schettkat, R. (ed.): The Flow Analysis of Labor Markets; London and New York, 14-36.

Schmähl, Winfried (1985): Prozeßproduzierte Längsschnittsinformationen zur Einkommensanalyse - Anmerkungen $\mathrm{zu}$ den Datenquellen; in: Allgemeines Statistisches Archiv 69, 275-285.

Schmähl, Winfried / Fachinger, Uwe (1994): Prozeßproduzierte Daten als Grundlage für sozial- und verteilungspolitische Analysen - Erfahrungen mit Daten der Rentenversicherungsträger für Längsschnittanalysen; in: Hauser, Richard / Ott, Notburga / Wagner, Gert (eds.): Mikroanalytische Grundlagen der Gesellschaftspolitik. Band 2: Erhebungsverfahren, Analysemethoden und Mikrosimulation; Berlin: Akademie Verlag, 179200.

Solga, Heike / Diewald, Martin (2001): The East German Labour Market after German Unification: A Study of Structural Change and Occupational Matching; in: Work, Employment and Society 15, 95-126.

Swinnerton, Kenneth A. / Wial, Howard (1995): Is Job Stability Declining in the U.S. Economy?; in: Industrial and Labor Relations Review 48, 293-304

Ureta, Manuelita (1992): The Importance of Lifetime Jobs in the U.S. Economy, Revisted; in: American Economic Review 82, 322-335.

Valetta, Robert G. (1999): Declining Job Security; in: Journal of Labor Economics 17, S170-S1197.

Voß, G. Günter (1998): Die Entgrenzung von Arbeit und Arbeitskraft. Eine subjektorientierte Interpretation des Wandels der Arbeit; in: Mitteilungen aus der Arbeitsmarkt- und Berufsforschung 28, 473-487.

Wagner, Alexandra (2000): Krise des „Normalarbeitsverhältnisses“? Über eine konfuse Debatte und ihre politische Instrumentalisierung; in: Schäfer, C. (ed.): Geringe Löhne - mehr Beschäftigung? Niedriglohn-Politik; Hamburg: VSA, 200-246.

Wagner, Gert G. (1999): Einige Bemerkungen zur Diskussion einer "Dienstleistungslücke" in (West)Deutschland; in: Beihefte der Konjunkturpolitik; No. 48, 77-92.

Wagner, Gert G. (2000): Erwerbsarbeit sollte Zukunft haben; in: Kocka, Jürgen / Offe, Klaus (eds.): Geschichte und Zukunft der Arbeit; Frankfurt a.M./New York: Campus, 215-233. 
Zukunftskommission (Kommission für Zukunftsfragen der Freistaaten Bayern und Sachsen) (1996): Erwerbstätigkeit und Arbeitslosigkeit in Deutschland. Entwicklung, Ursachen, Maßnahmen. Teil 1: Entwicklung von Erwerbstätigkeit und Arbeitslosigkeit in Deutschland und anderen frühindustrialisierten Ländern; Bonn. 